\title{
Correction to: Introducing Informatics in Primary Education: Curriculum and Teachers' Perspectives
}

\author{
Valentina Dagienė (D), Tatjana Jevsikova (D), \\ and Gabrielè Stupuriené $\mathbb{D}$
}

\section{Correction to: \\ Chapter "Introducing Informatics in Primary Education: Curriculum and Teachers' Perspectives" in: S. N. Pozdniakov and V. Dagienė (Eds.): Informatics in Schools, LNCS 11913, https://doi.org/10.1007/978-3-030-33759-9_7}

In the original version of this paper the affiliation was correct only for the author Valentina Dagienè. For authors Tatjana Jevsikova and Gabrielè Stupurienè affiliation has been corrected to:

Vilnius University Institute of Data Science and Digital Technologies, Vilnius, Lithuania. 